\title{
CHAPTER II. NATIONAL UTILIZATION GOALS AND ESTIMATES
}

This chapter presents the IGCC's goals and examines estimates of the level of geothermal energy production at various dates in the future. It looks at future geothermal energy production in four ways:

- The goals or target levels of production, selected by the IG C C

- Expected levels of production, as viewed from the perspective of various forecasters, independent of the IG C C goals

- The resource base, and amount of geothermal energy available for extraction

- Costs of production, specifically the relationship of cost and expected production levels for hydrother $\mathrm{m}$ al resources.

\section{A. NATIONAL GEOTHERMAL UTILIZATION GOALS .}

The IGCC's estimates of the achievable commercial utilization of geothermal resources in the United States are presented in Tables II.I and II.2. These goals provide a basis for framing Federal, state, and local policies and for determining measures necessary to increase the use of geotherm al energy.

The goals incorporate knowledge of existing and planned geothermal development. They are based in part on the quantity of the exploitable geothermal resources in the United States, and in part on estimates of how. rapidly the resources could be exploited in a technically feasible manner. Some consideration is made of the relative cost of geothermal versus other energy forms. Environmental problems are assumed not to be major impedim ents affecting the goals.

The hydrothermal electric goal for 1985 is 3,000 M We. Approximately 2,500 M We capacity is on line or firmly planned to be on line by 1985 . Intentions have been announced to build other plants, but firm plans have not been made. To meet the 1985 goal, decisions would have to be made within the next year or so to build about 500 M We additional capacity. An aggressive, supportive Federal program can accom plish this.

The hydrothermal electric goals are 25,000 M We of generating capacity on line in 2000 and $50,000 \mathrm{MWe}$ in 2020. Meeting these goals will require continued aggressive exploration through 2010, identification of new prospects, technology to produce electricity from reservoir fluids down to $150^{\circ} \mathrm{C}$, and a financial climate that ensures that successive $100 \mathrm{MWe}$ plants will be installed at three-year intervals at each prospect, until the currently estimated production capacity of each prospect is developed. The methods used to set these goals are described in Appendix $\mathrm{C}$.

The hydrothermal direct heat utilization goals are 1 quad/yr in 2000 and 6 quads/yr in 2020. Reaching these goals will require continued exploration and assessment of the lower temperature resources, reservoir 


\section{DISCLAIMER}

This report was prepared as an account of work sponsored by an agency of the United States Government. Neither the United States Government nor any agency Thereof, nor any of their employees, makes any warranty, express or implied, or assumes any legal liability or responsibility for the accuracy, completeness, or usefulness of any information, apparatus, product, or process disclosed, or represents that its use would not infringe privately owned rights. Reference herein to any specific commercial product, process, or service by trade name, trademark, manufacturer, or otherwise does not necessarily constitute or imply its endorsement, recommendation, or favoring by the United States Government or any agency thereof. The views and opinions of authors expressed herein do not necessarily state or reflect those of the United States Government or any agency thereof. 


\section{DISCLAIMER}

Portions of this document may be illegible in electronic image products. Images are produced from the best available original document. 
Table II.1

NATIONAL GEOTHERMAL UTILIZATION GOALS (BY APPLICATION)

\begin{tabular}{|c|c|c|c|c|c|c|c|}
\hline Electric Power Capacity (MWe) & 1980 & 1985 & 1990 & 1995 & 2000 & $\underline{2010}$ & 2020 \\
\hline Hydrothermal & 663 & 3,000 & 7,000 & 14,000 & 25,000 & 38,000 & 50,000 \\
\hline Geopressured (thermal) ${ }^{a}$ & 0 & 10 & 70 & 500 & 2,000 & 3,500 & 5,000 \\
\hline Hot Dry Rock & $\underline{0}$ & 10 & 35 & 135 & 700 & 1,900 & 6,800 \\
\hline Total MWe (Rounded) & 663 & 3,000 & 7,100 & 14,600 & 28,000 & 43,000 & 62,000 \\
\hline $\begin{array}{l}\text { Fossil Fuel Equivalent } \\
\text { Energy (in quads) }\end{array}$ & 0.05 & 0.24 & 0.6 & 1.2 & 2.2 & .3 .4 & 4.9 \\
\hline Direct Thermal Applications ${ }^{c}$ & & & & & & & 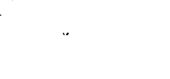 \\
\hline Hydrothermal & 0.01 & 0.1 & 0.2 & 0.4 & 1.0 & 3.0 & 6.0 \\
\hline Hot Dry Rock & 0.00 & 0.001 & 0.001 & 0.004 & 0.007 & 0.015 & -0.6 \\
\hline Geopressured Methane & 0.00 & 0.02 & $\underline{0.1}$ & 0.7 & 3.0 & 5.0 & 7.0 \\
\hline TOTAL (Rounded). & 0.06 & 0.40 & 0.9 & 2.3 & 6.2 & 11.5 & 18.5 \\
\hline
\end{tabular}

${ }^{a}$ Geopressured hydraulic energy assumed devoted to on-site parasitic loads.

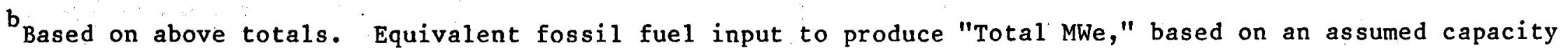
figure of 0.80 and an equivalent efficiency of fossil fuel plants of 0.33 .

From hydrothermal and hot dry rock systems only. Goals not set for geopressured (see Table II.2). 
Table II. 2

NATIONAL GEOTHERMAL UTILIZATION GOALS (BY RESOURCE TYPE)

(QUADS/YEAR)

\begin{tabular}{|c|c|c|c|c|c|c|c|}
\hline & 1980 & 1985 & 1990 & 1995 & 2000 & 2010 & 2020 \\
\hline \multicolumn{8}{|l|}{ Hydrothermal } \\
\hline Electric Applications & 0.05 & 0.24 & 0.6 & 1.1 & 2.0 & 3.0 & 4.0 \\
\hline Direct Thermal Applications & 0.01 & 0.1 & 0.2 & 0.4 & 1.0 & 3.0 & 6.0 \\
\hline \multicolumn{8}{|l|}{ Geopressured } \\
\hline Electric Applications & 0.00 & 0.001 & 0.006 & 0.04 & 0.16 & 0.3 & 0.4 \\
\hline Direct Thermal Applications & - & - & - & - & - & - & - \\
\hline Methane & 0.00 & 0.02 & 0.1 & 0.7 & 3.0 & 5.0 & 7.0 \\
\hline \multicolumn{8}{|l|}{ Hot Dry Rock (Estimates only) } \\
\hline Electric Applications ${ }^{a}$ & 0.00 & 0.001 & 0.003 & 0.01 & 0.06 & 0.15 & 0.5 \\
\hline Direct Thermal Applications & .0 .00 & 0.001 & 0.001 & 0.004 & 0.007 & 0.015 & 0.6 \\
\hline TOTAL (Rounded) & 0.06 & 0.4 & 0.9 & 2.3 & 6.2 & 11.5 & 18.5 \\
\hline
\end{tabular}

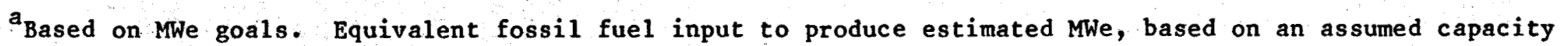
factor of 0.80 and an equivalent efficiency of fossil fuel plants of 0.33 .

As yet, the markets for nonelectric applications of geopressured energy sources are not well enough defined to establish meaningful objectives.

${ }^{c}$ These are not yet set as goals; only estimates of production are possible at this time. 
confirmation, substantial user education and technical assistance, and some degree of relocation of commercial and industrial users.

The goals for energy from geopressured resources are 2,000 MWe and 3 quads/yr methane production by 2000, and 5,000 MWe and 7 quads/yr methane production by 2020. Reaching these goals will require proof of the technical feasibility of resource exploitation by about 1983, no significant adverse findings from ongoing environmental studies (primarily waste disposa1), and no significant degree of subsidence in production areas. To meet these goals, utilization of offshore resources may be' needed.

Goals have not been set for hot dry rock, but potential productivity estimates for electricity and direct heat have been made. About 700 MWe and 0.007 quads/yr are possible by 2000, 6,800 Mhe and 0.6 quads/yr by 2020. Meeting these goals will require extensive characterization of the hot dry rock resource; the development of effective and economical technology for extracting thermal energy, and significant improvements in technology for drilling deep holes in hot hard rock.

Reaching the 1985 goal of 0.1 quads/yr for direct heat use will require that the pace of the development activity be increased above current levels. One well with a flow rate of 500 gallons/minute can feed a direct heat system (with a 60 percent conversion efficiency and a $38^{\circ} \mathrm{C}$ temperature drop) that will produce about $1.3 \times 10^{11} \mathrm{Btu} / \mathrm{yr}$ of heat for end use. To produce the equivalent of one quad $\left(10^{15} \mathrm{Btu}\right)$ of fossil fuel equivalent input per year would require the use of about 2,300 major production wells. To meet the 0.1 quad goal would require drilling perhaps 500 potential production wells and 200 additional wells for injection in six years, or about 115 major wells per year.

It seems unlikely that this goal can be met without a very strong Federal program. The current pace of development seems unlikely to support this goal. Plans have been proposed for about 0.005 quad of new development through 1985 (Geothermal Progress Monitor Report 非, January 1980). The geothermal industry drilled about 60 major wells in 1978, of which most were in high-temperature (potential electric) prospects and about half in the Geysers steam-electric field. Attaining the direct heat goal would require a tripling of current geothermal drilling rates for that purpose alone. Planned direct heat project starts would have to increase by a factor of 20 within the next 2 to 3 years.

The 1985 direct heat use goal of 0.1 quads per year i.s achievable if current activities are accelerated during the next few years. Four coordinated efforts could boost geothermal energy use fiftyfold from the current level of about 0.002 quads per year. These efforts are: the geothermal loan guarantee program, commercialization projects, Federal reservoir definition projects, and private industry efforts.

The geothermal loan guarantee program, by working at budget levels already authorized, could guarantee 15 new projects of 0.001 quads per year. The direct heat commercialization program would share the costs of 60 projects, 22 of which are already funded and in pragress. Together, these projects would require about 60 new wells, and result in 0.0005 quads per average use per project. The reservoir definition program would share 
C

Table II.3

SUMMARY OF NONELECTRIC USE ON-LINE, 1979*

\begin{tabular}{|c|c|c|c|c|c|}
\hline AREA OF USE & $\begin{array}{l}\text { NUMBER OF } \\
\text { USERS }\end{array}$ & FEDERAL & $\begin{array}{cc}\text { FUNDING } & (\$ 000) \\
\text { STATE } & \text { LOCAL }\end{array}$ & PRIVATE & $\begin{array}{c}\text { BTU/YgAR } \\
\left(10^{9}\right)\end{array}$ \\
\hline SPACE AND PROCESS USES & 180 & 63,992 & 6,014 & 1,071 & $1,386.2$ \\
\hline BATHS AND POOLS & & & 2 & 73 & 51.8 \\
\hline ENHANCED OIL RECOVERY & & & 2 & unknown & $10,000.0$ \\
\hline
\end{tabular}

$\begin{array}{llllllll}\text { TOTAL } & 271 & 63,992 & 6,694 & 6,023 & 11,438.0\end{array}$

* Based on data in the Geothermal Progress Monitor, Issue Number 1 , December $1979^{\circ}$. 
Table II.4

COMPARISON OF HYDROTHERMAL ELECTRIC FORECASTS

(MWe On-Line by End of Stated Year)

\begin{tabular}{|c|c|c|c|c|c|c|c|c|c|}
\hline FORECAST & DATE & BASIS & & 1979 & 1980 & 1985 & 1990 & 1995 & 2000 \\
\hline IGCC Goals ${ }^{a}$ & 1979 & Resource Potential and Economics & & & 663 & 3,000 & 7,000 & 14,000 & 25,000 \\
\hline DGRM $^{\mathrm{b}}$ & 1979 & $\begin{array}{l}\text { General Knowledge of Developer/ } \\
\text { Utility Plans }\end{array}$ & & 663 & 941 & 2,470 & 3,330 & - & - \\
\hline EPRI Forecást & 1979 & EPRI R\&D Plans & $\therefore$ & - & & 6,000 & 9,650 & - & 25,000 \\
\hline EPRI Survey ${ }^{d}$ & 1979 & $\begin{array}{l}\text { Survey of Industry Estimates: } \\
\text { - Announced } \\
\text { - Probable } \\
\text { - Possible }\end{array}$ & & $\begin{array}{l}- \\
-\end{array}$ & $\overline{-}$ & $\begin{array}{l}2,057 \\
2,564 \\
2,999\end{array}$ & $\begin{array}{l}2,242 \\
4,577 \\
6,443\end{array}$ & - & $\begin{array}{r}2,832 \\
7,288 \\
10,888\end{array}$ \\
\hline $\begin{array}{l}\text { NRC CONAES } \\
\text { Geothermal } \\
\text { Resource } \\
\text { Panel }\end{array}$ & $\begin{array}{l}1979 \\
\cdots\end{array}$ & $\begin{array}{l}\text { Panel of Experts } \\
\text { - Business as Usual } \\
\text { - Moderately Accelerated Development } \\
\text { - Strong1y Accelerated Development } \\
\text { - Crash Development }\end{array}$ & & $\begin{array}{l}- \\
- \\
-\end{array}$ & $\begin{array}{r}860 \\
970 \\
1,180 \\
1,380\end{array}$ & $\begin{array}{l}1,480 \\
2,160 \\
2,620 \\
3,130\end{array}$ & $\begin{array}{l}2,520 \\
3,500 \\
6,600 \\
9,900\end{array}$ & $\begin{array}{l}- \\
\overline{-} \\
-\end{array}$ & $\begin{array}{r}5,500 \\
8,400 \\
16,100 \\
26,600\end{array}$ \\
\hline $\begin{array}{l}\text { Commerce } \\
\text { Department }\end{array}$ & 1977 & $\begin{array}{l}\text { "Most Likely" Supply/Demand } \\
\text { Balance }\end{array}$ & 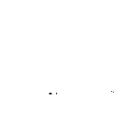 & - & 1,000 & 2,000 & - & - & 20,000 \\
\hline $\begin{array}{l}\text { EIA Annual Report } \\
\text { to Congress } 1978^{8}\end{array}$ & 1978 & Mid Range Economic Growth and oil Price & Case & - & - & 2,600 & 4,500 & 6,200 & - \\
\hline
\end{tabular}

$a_{b}$ Table II. 1 this report.

Geothermal Progress Monitor Report \#1, December 1979.

dEPRI New Energy Resource Department Strategy Paper, January 1979.

${ }^{d}$ V. Roberts and P. Kruger, Geothermal Resources Council Transactions, Vo1. 3, September 1979.

Geothermal Resources and Technology in the United States; National Academy of Sciences, 1979.

Forecast of Likely, U.S. Energy Supply/Demand Balances for 1985 and 2000 and Implications for U.S. Energy Policy,

U.S. Department of Commerce, 20 January 1977.

$\mathrm{E}_{\mathrm{U} . S .}$. D.E. Energy Information Administration, Annual Report to Congress 1978, Vol. 3, Supplement 1. C) 
the costs of about 50 projects. Each successful project is estimated to use 0.0005 quads per year.

The projects above are assumed to stimulate one private sector project for every two projects with substantial Federal involvement. These "leveraged" projects would number about 60 successful projects averaging 0.0005 quads per year per project.

Summed across these four efforts, there would be about 210 attempted new project starts, of which about 160 would be successful. About 300 new wells (about 180 successfu1) would be drilled during calendar years 1980 through 1984, an average of about 60 new wells for direct use per year. Together these would produce 0.1 quads per year.

\section{B. ESTIMATES OF GEOTHERMAL UTILIZATION}

Most of the estimates of geothermal energy utilization that can be made with a reasonable degree of confidence are for hydrothermal electric applications. The resource assessment work of the U.S. Geological Survey and announced plans of field developers and electric utility companies provide a useful basis for estimating rates of development.

In contrast, estimates of hydrothermal nonelectric use, geopressured methane production, and extraction of other energy from geopressured and hot dry rock resources are clouded by uncertainties concerning the size of the producible resource, co-location of resources and markets, and the economics of production. Table II. 3 presents current estimates of the current geothermal energy as a nonelectric energy source.

Estimates of geothermal hydrothermal electric utilization in the United States from a number of recent assessments are shown in Table II.4. The IGCC hydrothermal electric goals from Table II.l are included for comparison.

For the near term, through 1985 , the results of the Electric Power Research Institute (EPRI) survey of electric utilities provide the most interesting results. Announced plans of utilities indicate a minimum of 2,000 MWe on line by the end of 1985 , with 2,500 MWe viewed as probable, and 3,000 MWe seen as possible.

There appears to be broad consensus from these estimates that by 1990 , about $3,500-4,500$ MWe could be installed given moderate stimulation, while an intense effort might result in somewhere between $7,000-10,000$ MWe.

Developments of resources after 1990 are difficult to predict due to lack of knowledge about the general economic climate and scarcity of knowledge about the number and size of hydrothermal resources in unexplored areas.

Forecasts for installation of hydrothermal electric plants by the end of $2000 \mathrm{fall}$ in the range of $11,000-25,000 \mathrm{MWe}$. Cost estimates and scheduling exercises suggest that about $13,000-15,000$ MWe could be developed from known resources by the year 2000 (see Appendix D). The IGCC goal for the year 2000 of 25,000 MWe assumes that many new high-quality 
resources will be discovered in the next decade. Almost all of the capacity installed through 1985 will be in California. Installed capacity at The Geysers field will still predominate. Significant development of resources in the Imperial Valley, California, and in other western states is expected in the $1985-1990$ period.

The Division of Geothermal Resource Management is estimating market share and market penetration of hydrothermal resources for direct heat utilization. These estimates require careful analyses for the co-location of resource and potential markets, and the match between resource characteristics and end-use temperature and heat rate needs.

The National Resource Council's (NRC) Geothermal Resource Panel (Reference $e$ in Table II.4) estimated that direct heat use by 2000 , from all forms of geothermal resources, will be less than 1 quad, even if crash development occurs. That panel identified a low degree of co-location between resource and cities, and lack of mobility of industrial users as major limits to growth of direct heat use. More recent studies, however, suggest that this goal can be met with an aggressive program.

The potential for hydrothermal electric generation for the years 1985, 1990, and 1995 was integrated into the projections made for Energy Information Administration's Annual Report to Congress 1978, published in mid-1979.

These projections are sensitive to a wide variety of parameters, including GNP projections, supplies of conventional fuels, and world oil prices; and are based upon the assumption that the governmental policies in force at the end of 1978 will continue unchanged. They should be regarded only as representative projections, but do provide some insight into the potential extent of application of electric generation using hydrothermal energy.

The input parameters relating to specific resources that were used for projecting hydrothermal electric generation were derived from a study done by the Mitre Corporation for the DOE geothermal program, and were provided to EIA by DOE's Office of Policy and Analysis.

In all of the projections, the vast majority of hydrothermal electric generation takes place in California, Nevada, and Arizona, with a small amount of generation in the Gulf Coast. In a few projections and years, a small amount of generation occurs in the Rocky Mountain States.

For the near term (1985), total U.S. hydrothermal electric generation is relatively insensitive to the projection parameters. This is to be expected, since commitments have already been made for most facilities likely to be operating by 1985.

Projected hydrothermal electric generation for 1990 and beyond is relatively sensitive to the availability of domestic supplies of alternative fuels. Low domestic supplies of conventional fuels (principally oil and natural gas), coupled with high world oil prices, could raise hydrothermal electric generation by more than 25 percent. 
Most 1995 hydrothermal electric generation capacity projections are on the order of 6,200 MWe. Low supplies of domestic oil and gas or a nuclear moratorium could raise generation by 50 to 60 percent.

A summary of estimates of the energy recoverable from geopressured geothermal resources in Louisiana and Texas made by LSU in 1978 are shown in Table II.5. The estimates of producible methane range from near zero to 52,000 quads. These estimates differ, because very little is known concerning how much brine can be produced from wells, the reservoir characteristics of each geopressured aquifer, the economics of production and reinjection, and the degree to which environmental effects such as ground subsidence could restrict production from specific fields along the Gulf coast.

\section{GEOTHERMAL RESOURCE POTENTIAL IN THE UNITED STATES}

In FY 79, the U.S. Geological Survey (USGS) published an update of its national geothermal resource assessment (USGS Circular 790, "Assessment of Geothermal Resources of the United States-1978," January 1979). Taken from this document, Table II.6 shows the current estimated potential of geothermal resources in the United States. The estimates include offshore geopressured resources, reported for the first time. In considering the energy estimates in this table, care must be taken to differentiate between the accessible resource base (total thermal energy in the ground to specified depth) and the resource (thermal energy that could be extracted economically within a reasonable time). To emphasize this important distinction, the resource estimates have been enclosed in a box with a bold line.

Circular 790 attempted the first tabulation of data of lowtemperature (less than $90^{\circ} \mathrm{C}$ ) geothermal waters at depths less than $1 \mathrm{~km}$. It was not possible to quantify the amount of geothermal energy in the ground or the amount of energy that might be recovered. Such lowtemperature waters appear to be widely available over much of the country and should have significant potential for space heating and agricultural applications. The USGS is increasing its effort to better understand waters in the low to moderate ranges $\left(20^{\circ}-150^{\circ} \mathrm{C}\right)$ and with more adequate data supplied by the DOE state-coupled program will complete an assessment within the next two years.

It should be noted that the geothermal resource assessment, because of its high level of aggregation, should not be used to establish specific reserve figures for short-term investment and marketing decisions. By its nature, this resource assessment is designed to be useful to industry and government in developing long-term policy and strategies. It is prepared using uniform methodology and data analysis to estimate the amount of thermal energy that might feasibly and economically be extracted from the earth at some future time.

Figure II. I shows those areas in the U.S. that have been identified as having known or potential hydrothermal resources. Data for this map were derived from the regional and national assessments performed by the USGS and from state and site-specific assessments performed under the DOE state-coupled program. The western U.S. has the greatest potential for 
SUMMARY OF RECOVERABLE GEOPRESSURED ENERGY ESTIMATES

(Louisiana-Texas Gulf Coast, Onshore and Offshore)

\begin{tabular}{|c|c|c|c|c|}
\hline SOURCE & THERMAL QUADS & & GAS QUADS & $\begin{array}{l}\text { ELECTRICITY } \\
\text { (MW centuries) }\end{array}$ \\
\hline Brown-Hudson & & & $2,400-52,000$ & \\
\hline Dorfman-Texas (Texas only) & & & & 20,000 \\
\hline Dorfman-Texas & & & 256 & \\
\hline Elmer-Tractor & $529-2,0.58$ & & 2,000 & $\ldots$ \\
\hline $\begin{array}{l}\text { Gould-Intercomp } \\
\text { (onshore Texas only) }\end{array}$ & & & 150 & 33,000 \\
\hline Hawkins-LSU (Louisiana only) & 19.5 & & 13.6 & \\
\hline Hise-LsU: & & & 125 & \\
\hline House-Livermore & & & 222 & 5,990 \\
\hline Jones-LSU & & & 1,146 & \\
\hline Myers-Livermore & & & $.0001-1,000$ & $0.1-100,000$ \\
\hline $\begin{array}{l}\text { Papadopulos-USGs } \\
\text { (Plan 2) } \\
\text { (Plan 3-1ower bounds) } \\
\text { (onshore only) }\end{array}$ & 1,424 & 77.38 & 768 & $\begin{array}{r}38,140 \\
2,880\end{array}$ \\
\hline Trehan-MITRE & & & $\therefore$ & 100,000 \\
\hline U.S. ERDA-Definition Report & & & $500-2,000$ & $33,400-110,000$ \\
\hline U.S. ERDA-MOPPS & & & $150-2,000$ & \\
\hline Wilson-Dow (Texas only) & & & 45.6 & 8,000 \\
\hline
\end{tabular}

C From: B. Wilkins, Office of Advanced Studies and Research, Louisiana State University, Baton Rouge, Report \#0R0-5442-1, February 1978. 
Table II. 6

GEOTHERMAL ENERGY OF THE UNITED STATES*

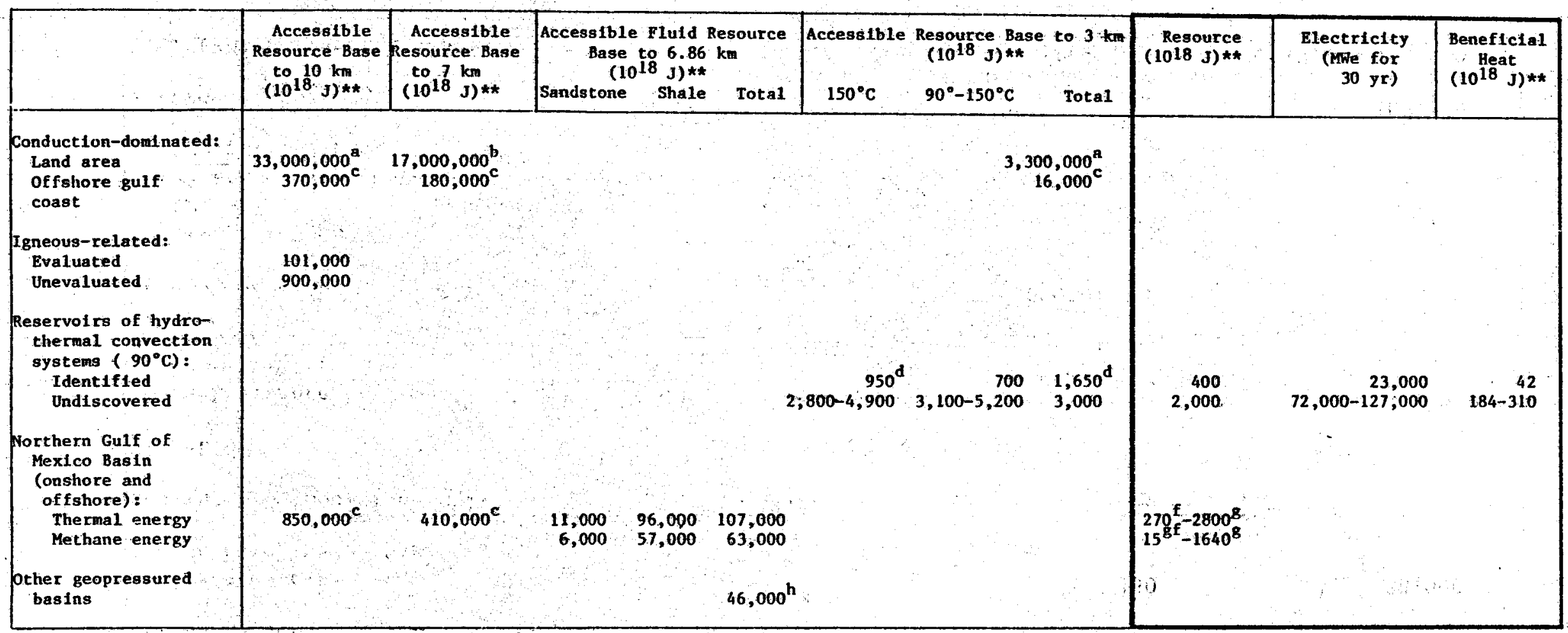

a. "Best estimates" of Diment and others (1975, Table 14). These values are each approximately 18 percent greater th an the values determined by the "basic Calculation" of Diment and others (1975, Tab1e 13).

b. Equations on p. 85 and 91 of Diment and others (1975) (assuming an expopential decrease of heat production with depth) give $11,700,000$ $x 10 \mathrm{~J}$. for the "basic calculation." This ralue is then increased by approximately 18 percent to give a figure comparable to the "best est1metes" of Diment and others (1975, Table 14).

c. Calculated for an area of $135,000 \mathrm{~km}^{2}$ using the "basic calculation" of Diment and others (1975) and the thermal parameters listed for the coastal plain on their Table 13. The result 18 then increased by approximately 18 percent to give a figure comparable their "best estimates." d. Does not include $1290 \times 10^{18} \mathrm{~J}$ in Nattonal Parks (main1y in Yellowstone).

e. Calculated for an area of $310,000 \mathrm{~km}^{2}$ using the "basic calculation" of Diment and others (1975) and the thermal parameters listed for the coastal plain on their Table 13. The result is then Increased by approxtmately 18 percent to give a figure comparable to their "best eatimates."

f. Plan 3 of Papadopulos, Wallace, Wesselman, and Taylor (1975).

g. Plan 2 of Papadopulos, Wallace, Wesselman, and Taylor (1975).

h. From White and williams (1975, Tab1e 28): thermal energy only.

* Table 20 of uSGS Circular 790, Assessment of Geothermal Resources of the United States, 1978.

$* * 10.18 \mathrm{~J} 1$ quad. 
Figure II.1

\section{Known and Potential Hydrothermal Resources}

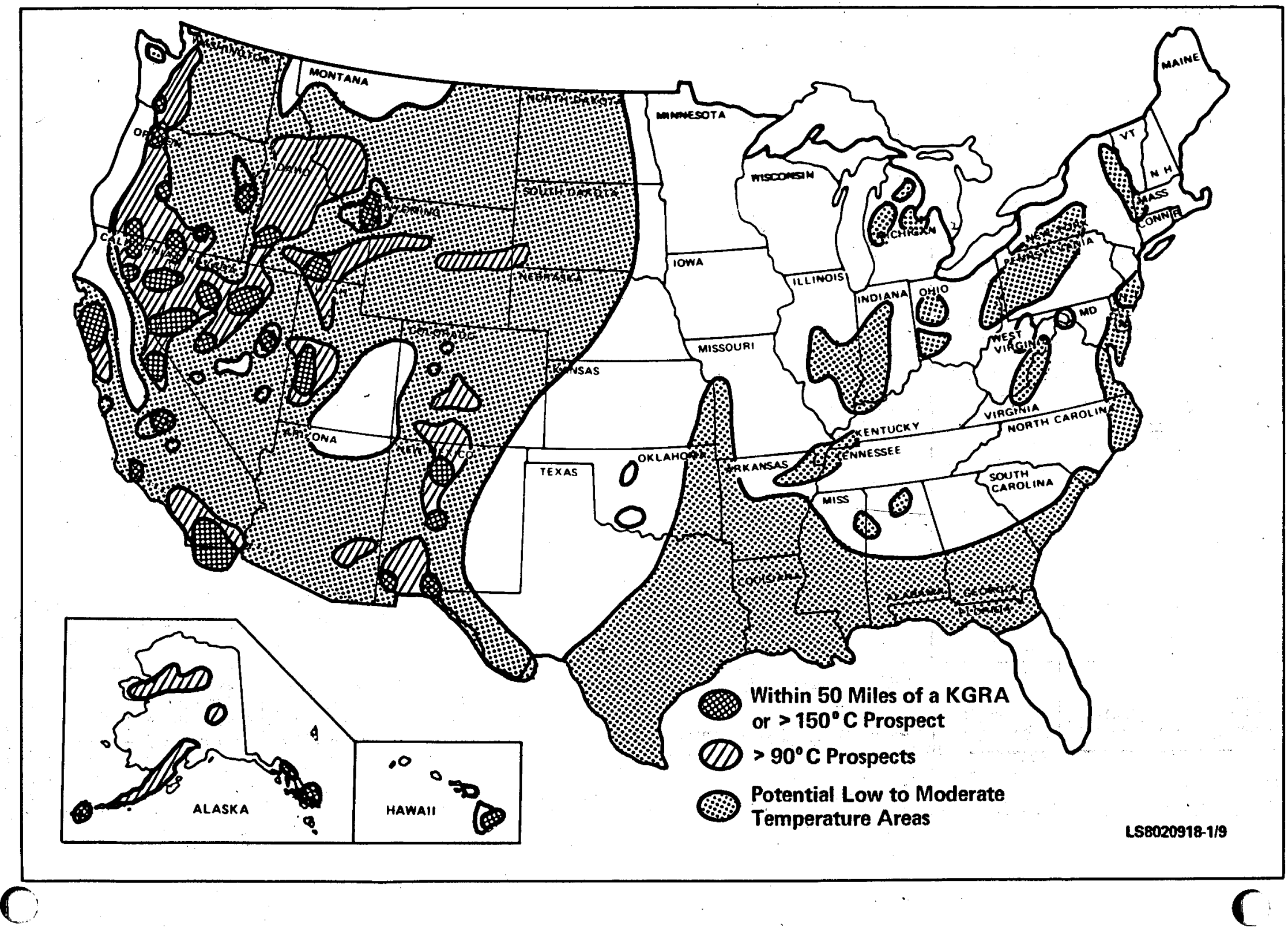


hydrothermal development, particularly for use in electrical power generation and direct heat applications that require relatively high te meratures. The Atlantic Coastal area and the southeastern U.S. contain a number of prospective targets for development as low- to moderatete merature heat sources.

\section{HY DROTHERMAL SUPPLIES AND ESTIMATED COSTS}

Utilization estimates depend on a number of factors, including the available supply of geothermal energy, the economics of energy extraction, the economics of energy conversion, and estimates of future demand for electricity and heat. The resource assessment activities of the U.S. Geological Survey and a number of economic studies were used for supply and cost estimates for hydrothermal electric and Fydrothermal direct heat applications. These are presented in this section to demonstrate that hydrothermal resource supplies are large and economical. Supply and cost curves for geopressured geothermal and hot dry rock resources are much more uncertain, and are not described here.

The hydrothermal supply estimates presented here are based on application of economic studies to resource estimates in USGS Circular 790, published in early 1979. Circular 790 describes both estimates of the energy potential at known specific hydrothermal sites, and estimates of inferred resources yet to be located.

Figures II.2, II.3, and $I .4$ present the estimates of potential electric energy at the 52 known prospects. These known prospects could supply about 21,000 M W of capacity for a 30 -year period. About half of the known hydrothermal electric resource is located in California, and almost all of the rest of it is in six other western states: New Mexico, Nevada, Oregon, Utah, Idaho, and Hawaii.

Six of the known locations appear to be able to support more than 1,000 MWe each for 30 years. These are the Salton Sea area, California; Valles Caldera (Baca Ranch), New Mexico; Mono-Long Valley, California; Westmorland, California; The Geysers, California; and Lake City-Surprise Valley, C alifornia.

Costed supply curves for hydrothermal electric and direct heat uses are shown as Figures $\Pi 1.5$ and $I$. 6 . These estimated curves were prepared by applying engineering cost models to the physical characteristics (volume, temperature, depth) of the known hydrothermal resources in USGS Circular 790.

Resources with estimated temperatures greater than $150^{\circ} \mathrm{C}$ are assumed to be used for electricity production, and lower temperature $\left(90-150^{\circ} \mathrm{C}\right)$ resources are assumed to be used for direct heat applications. The USGS estimates that the undiscovered hydrothermal electric resource is about four times the known resource, while the undiscovered direct heat resource is about five times the known resource. The hydrothermal electric cost model and the direct heat cost model were prepared by the Mitre Corporation and Battelle Pacific Northwest Laboratories, respectively. The detailed assum ptions used in these costing models are described in Appendix D. 
Figure 11. 3 POTENTIAL ELECTRICAL ENERCY (MWe FOR 30 YEARS FROM KNOWN HOT WATER HYDROTHERYAL SYSTEMS $\left(\$ 150^{\circ} \mathrm{C}\right.$ )*
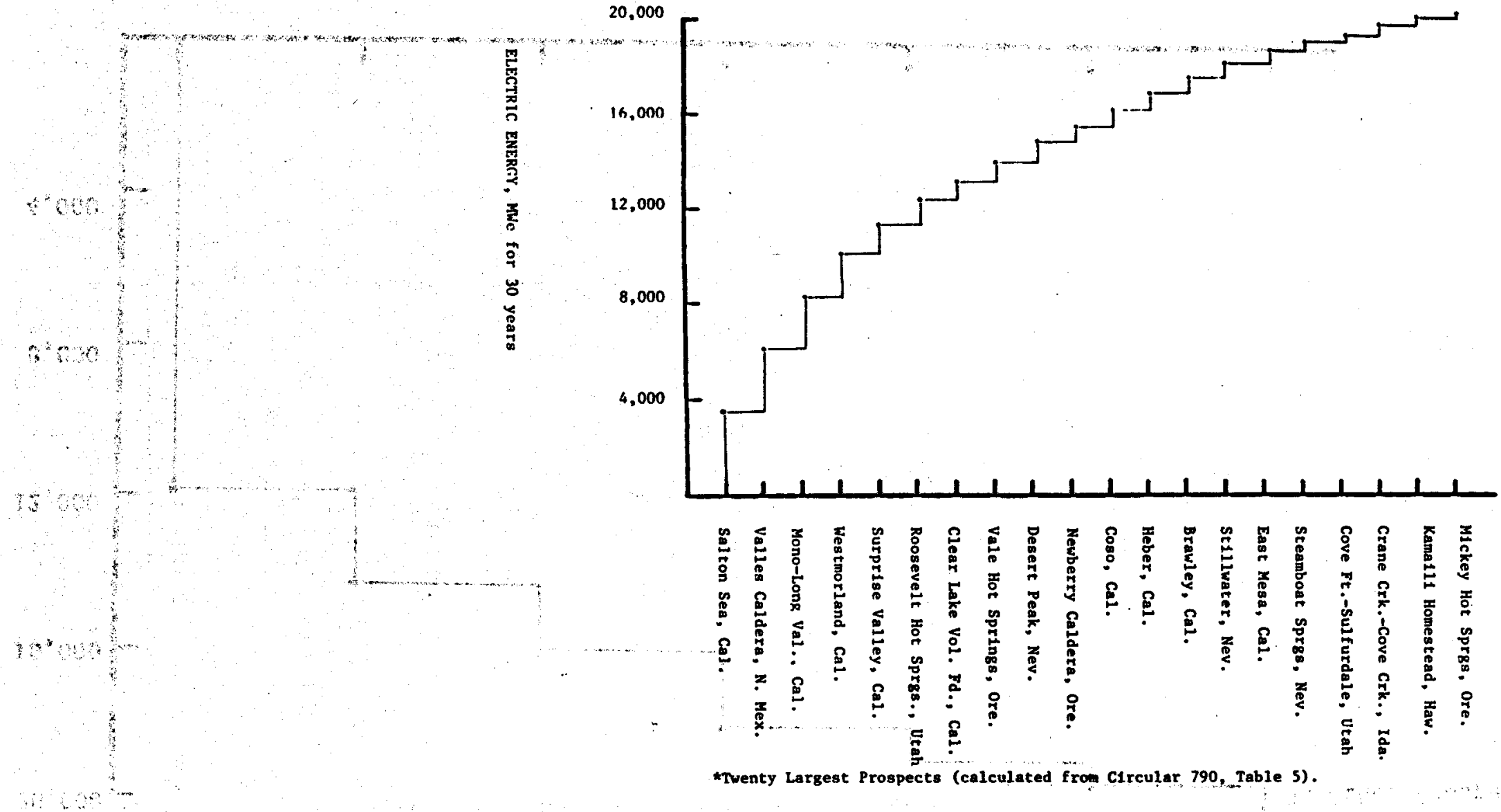

*Twenty Largest Prospects (calculated from C1rcular 790, Table 5). 
Figure II. 4

POTENTIAL FOR ELECTRIC ENERGY (MWe FOR 30 YEARS) FROM KNOWN HOT WATER HYDROTHERMAL SYSTEMS ( $>150^{\circ} \mathrm{C}$ )*

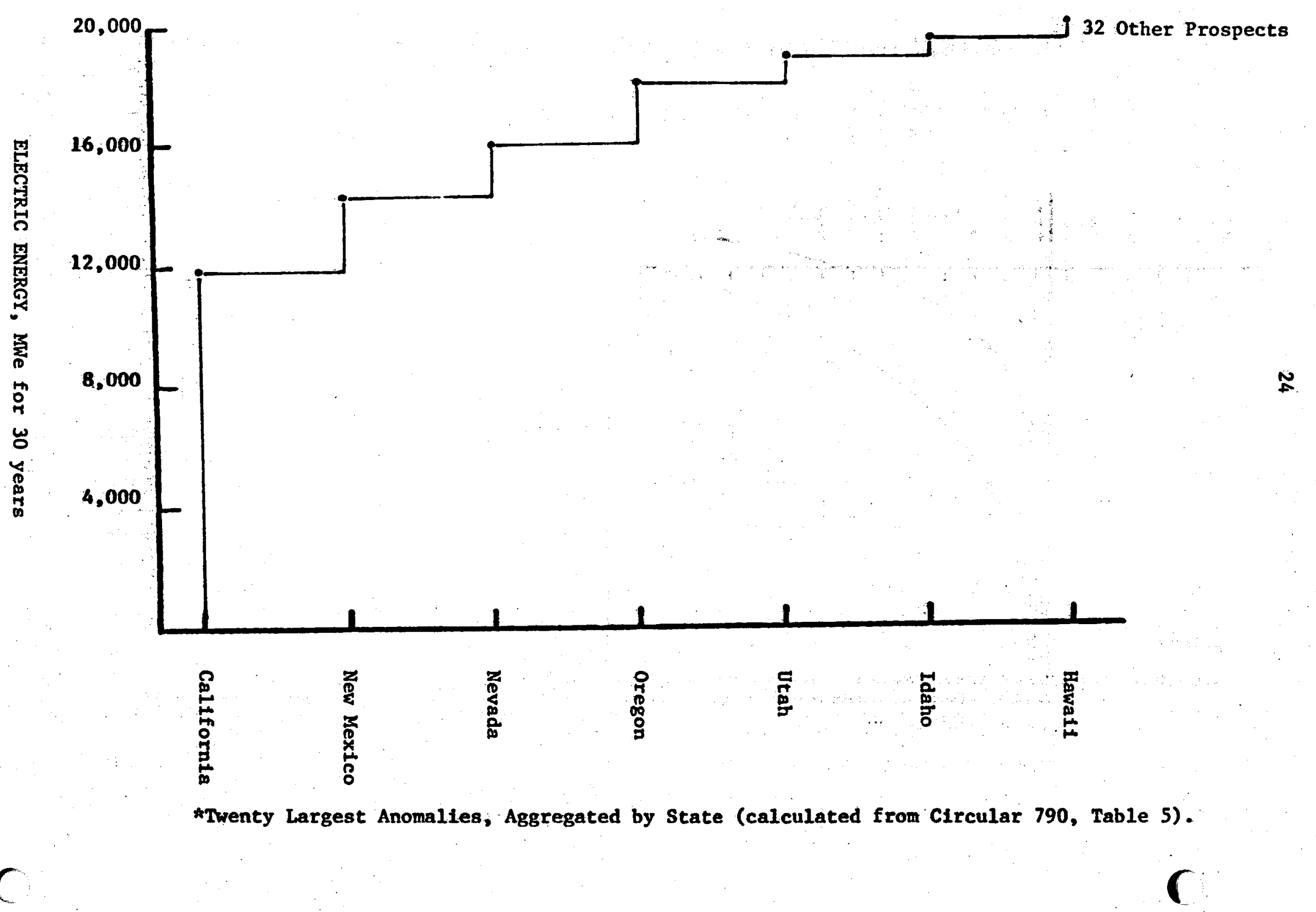


Figure II. 5

COST CURVES FOR GEOTHERMAL (HYDROTHERMAL) ELECTRICITY

1,000 MWe For 30 Years of Reservoir Capacity (Cumulative) - Known \& Inferred Resources* .

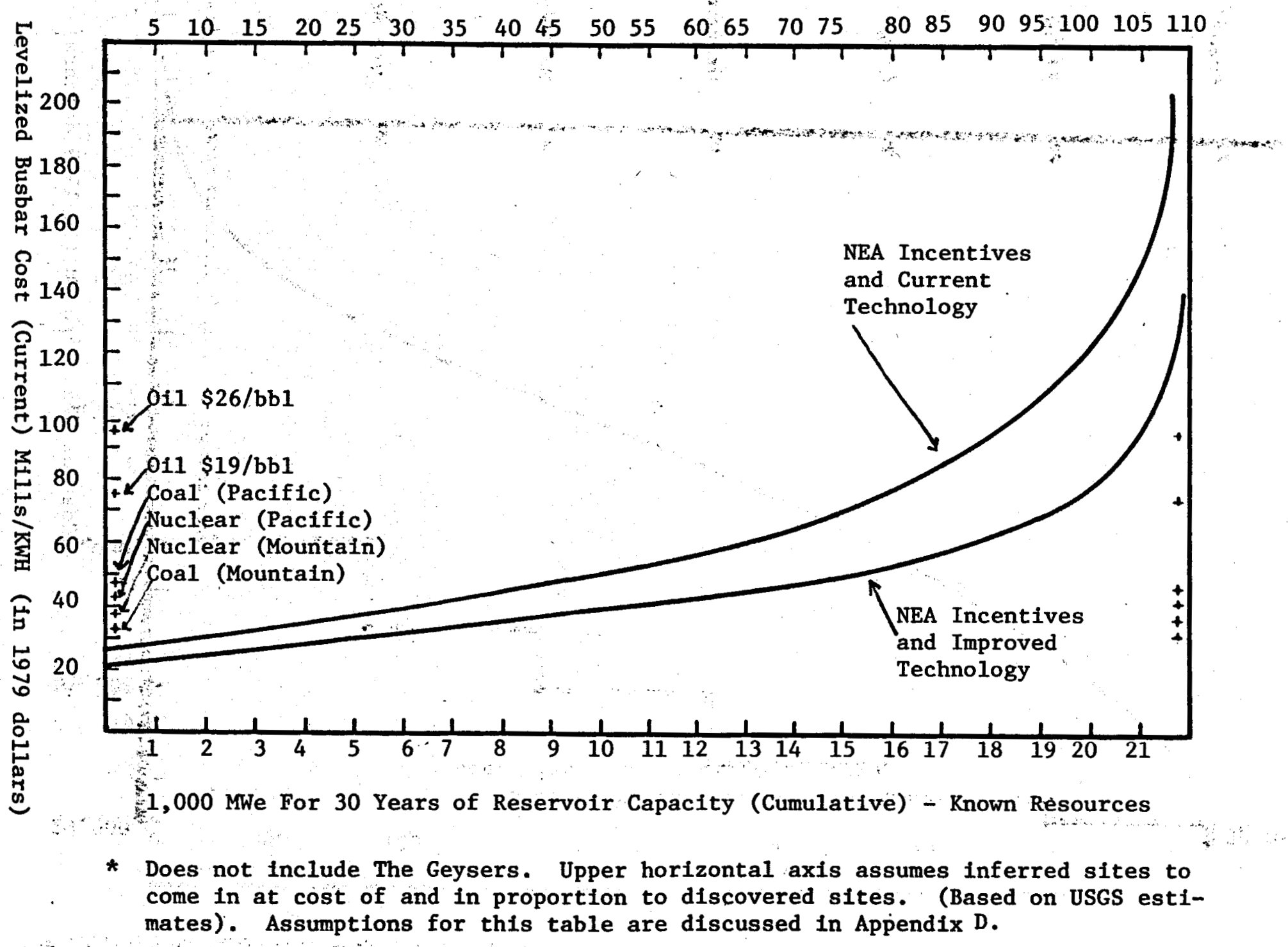


Figure II.6

COMPOSITE NONELECTRIC RESOURCE AVAILABILITY CURVE ${ }^{1}$

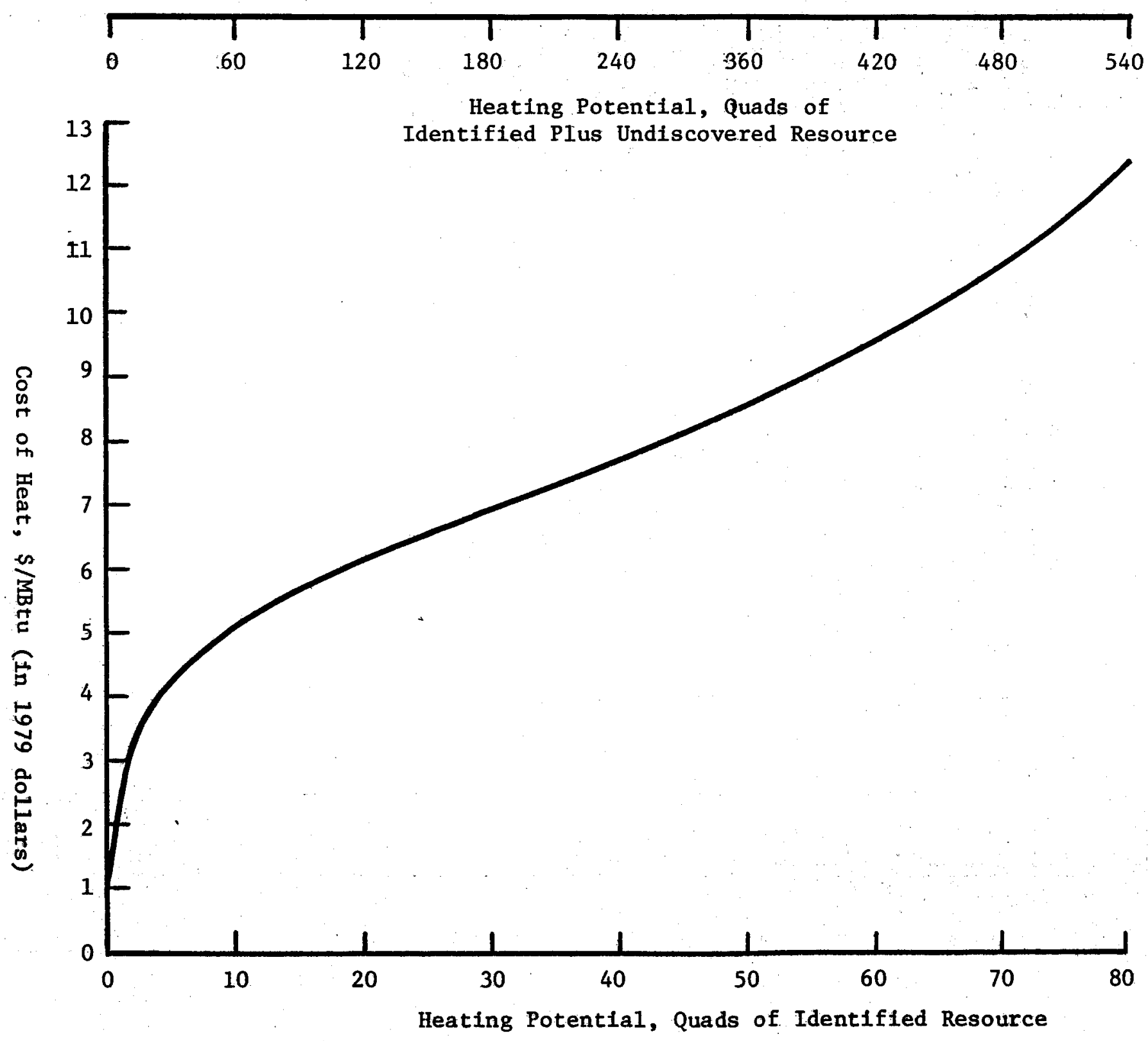


The electric cost curve (Figure II.5) is based on the installation of 50 MWe plants of double-flash design at high-temperature prospects and binary-cycle plants at moderate-temperature prospects. The cost estimates include the incentives provided for in the 1978 National Energy Act (NEA). The upper of the two curves is based on the costs of available technology. The lower curve includes estimates of the cost-reducing impacts of the Atiproved technology that are expected to result from Department of Energy geothermal research and development programs and used in commercial installations by 1990 .

The electric cost curves assume that installation and operation proceeds with no problems, and with no elaborate environmental controls. Exploration costs are not included, since these can be very high for a first plant and relatively low for additional plants. These assumptions imply that the cost of power from the first plant at each site could be significantly higher than (perhaps even double) the cost shown here. Costs are measured in 1979 dollars.

The direct heat cost curve assumes that one-third of the available lower temperature resources will be used for urban district heating, for suburban district heating, and for industrial process heat. This cost curve reflects the efficiency of utilization, which should be taken into account in comparisons with the costs of competing energy resources. For example, the efficiency of utilization for space heating with oil is between 50 and 70 percent, but the efficiency of utilization for space heating with geothermal is nearly 100 percent. At current prices, with current technology, 20 quads of identified resource and 120 quads of identified plus undiscovered resource are available at $\$ 6$ per million Btu (Figure II.6); 80 quads of identified resource and 540 quads of identified plus undiscovered resource are available at $\$ 13$ per million Btu. Detailed assumptions used in these costing models are described in Appendix $D$.

Estimates for direct applications assume current technology only. If the recent achievements and projected breakthroughs in low-cost, highefficiency technology are figured in, the costs will become even more competitive. 


\section{Raft River, Idaho, Well Test}

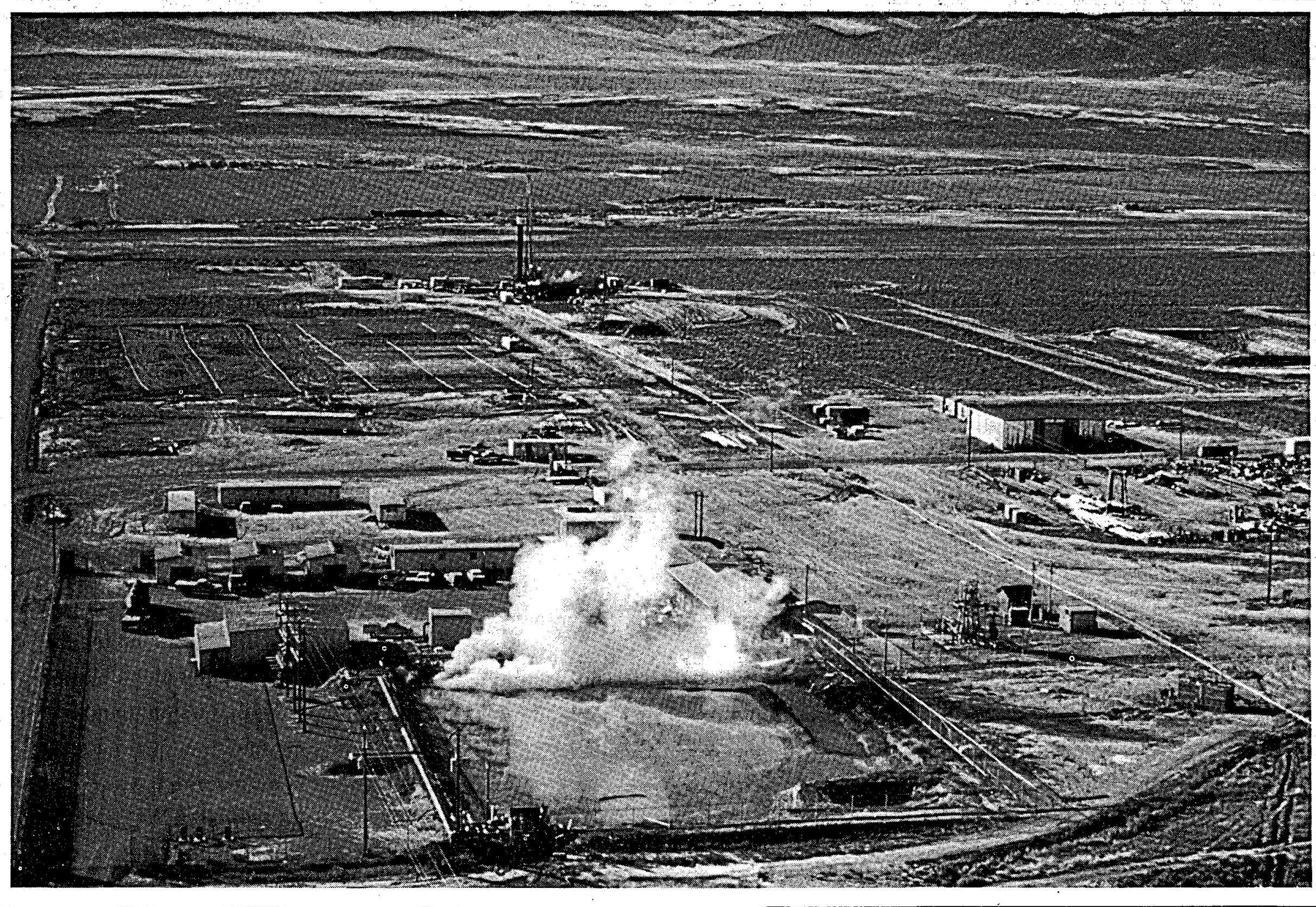

